\section{Rede Mundial}

\section{0 anos da internet no Brasil: universalização do acesso em expansão}

Em 1991, o Brasil assistiu aos primeiros ensaios de conexôes à incipiente internet, a entre-redes, a rede das redes de computadores. Naquela época o privilégio de poder trocar mensagens eletrônicas era coisa restrita aos pesquisadores universitários, pois a internet brasileira era uma rede exclusiva para universidades e centros de pesquisa. Hoje são cerca de 50 milhôes de usuários no país, mas que ainda pedem por universalização do acesso. Caso emblemático de urgência por conectividade foi o fato de, neste ano, a Receita Federal ter restringido, pela primeira vez, a entrega de declarações anuais de imposto de renda à via eletrônica. Ricardo Fritsch, coordenador da Associação Software Livre (ASL.Org) diz que "idealmente nós deveríamos ter um único tipo de cidadão, o cidadão conectado. Mas hoje ainda temos diferença entre os cidadãos de primeira categoria, que estão conectados, e os de segunda categoria, que têm que se deslocar até uma repartição pública, que pode estar na sua cidade ou até mesmo em uma cidade vizinha".

A Fundação de Amparo à Pesquisa do Estado de São Paulo (Fapesp) e o
Instituto Brasileiro de Análises Sociais e Econômicas (Ibase), no Rio de Janeiro, lideraram o esforço de conexão à grande rede. Desde então, a internet tem se caracterizado como uma tecnologia altamente disruptiva. Ela atua fornecendo soluçōes novas e originais para velhos problemas, ao invés de simplesmente incrementar ou otimizar soluções já existentes. Foi assim com a primeira revolução, o correio eletrônico, depois com o comércio online e, simultaneamente, o compartilhamento de arquivos. Esta última tecnologia tem protagonizado a mais profunda alteração na forma como se distribuem bens simbólicos, como filmes, músicas e livros. E, como tal, tem sido também a atividade online com mais desdobramentos éticos, políticos e tecnológicos, impactando em toda a sociedade.

No Brasil, o aniversário de duas décadas da internet demarca uma série de avanços importantes, mas também expõe fragilidades e disputas. Em termos de avanços e consolidaçôes, pode-se citar a criação e atuação do Comitê Gestor da Internet Brasileira (CGI.br), através da Portaria Interministerial $147 \mathrm{em}$ 1995, e o Decreto 4.829/2003 que a altera. O CGI.br foi criado para "coordenar e integrar todas as iniciativas de serviços de internet no país, promovendo a qualidade técnica, a inovação e a disseminação dos serviços ofertados". O CGI.br trabalha em conjunto com o Núcleo de Informação e Coordenação do Ponto Br (NIC.br) que, por sua vez, atua como um braço executor das deliberações do CGI.br e também opera o Registro.br, através do qual a entrega de domínios com terminação ".br" é coordenada, bem como seus endereços IP. Esse arranjo institucional foi criado em conjunto pelos Ministérios das Comunicaçōes e da Ciência e Tecnologia, em maio de 1995, com fins de promover a efetiva participação $\mathrm{da}$ sociedade civil em assuntos $\mathrm{da}$ internet brasileira.

Apesar do crescimento do acesso digital, ainda é baixa a penetração da rede na sociedade. Ela está altamente concentrada nos grandes centros urbanos, excludente às populações de baixa renda e as localizadas em periferias urbanas e regiōes rurais, sendo que o acesso em banda larga nas regiōes Norte e Nordeste é mais precário do que no restante do país. De acordo com dados da Agência Nacional de Telecomunicações (Anatel), em dezembro de 2010 havia somente 50 milhões de usuários - em uma população de $190 \mathrm{mi}$ lhões, ou $26 \%$ dos brasileiros - com acesso à internet em modalidade banda larga fixa (cabo ou dsl). Nesse cenário, parece distante o uso da internet como uma ferramenta de educação universal, de acesso a serviços do governo (e-Gov) e de liberdade de opinião e informação. 
empresas (Oi, NET e Telefônica) concentravam $84,3 \%$ da participação no mercado nacional. No Norte e Nordeste a situação é ainda mais dramática e, não raro, uma única empresa domina o fornecimento do serviço. Na ausência de competição, não impressiona que os preços do serviço para esses estados sejam os mais caros do país.

O PNBL entra justamente para intervir nessa concentração, tanto do oligopólio quanto da distribuição no território nacional. Como a infraestrutura mais cara é a instalação de conectividade capaz de interligar todo o país, o PNBL fará essa interligação e a partir de sua rede seria possível provedores privados oferecerem conectividade local a comunidades, zonas rurais e cidades. O governo, nesse cenário, seria um provedor de conexão "no atacado", e o setor privado responsável pelo que se conhece como "última milha", ou seja, a ligação entre a residência do assinante e a rede do governo.
No final de maio e começo de junho o PNBL sofreu algumas reviravoltas. A destituição de Rogério Santanna do cargo de presidente da Telebrás e a nomeação de Caio Bonilha, então diretor comercial da estatal, no dia 1ㅇ de junho, foram vistos por muitos como uma indicação de que o governo pretendia aproximar-se das telecoms, dando sinais claros de que não pretende atuar no varejo. Outro problema enfrentado pela Telebrás foi o contingenciamento de recursos decretado pela presidente Dilma Rousseff. Face à nova dotação, as metas do PNBL para o ano de 2011 ficam severamente comprometidas.

\section{DIREITO DE ACESSO E NEUTRALIDADE}

O senador Rodrigo Rollemberg (PSB-DF) é autor de uma proposta de emenda constitucional que planeja inserir na Carta Magna o direito ao acesso à internet, a exemplo de países como a Finlândia, que declarou o acesso à internet banda larga um direito de todos os finlandeses em 2009, sendo o primeiro país a aprovar isso em lei.

A neutralidade da internet é, ao mesmo tempo, uma circunstância resultante da forma como os protocolos de troca de dados foram desenvolvidos, e também um aspecto social desejável, uma vez que a internet é uma rede distribuída e descentralizada, onde qualquer um opera em igualdade de condiçôes com seus pares. A manutenção futura da neutralidade - que tem origem no início da história da rede - tem sido um tema fortemente debatido, uma vez que existem pressões políticas e lobbies fortes que buscam relativizá-la. Os motivos para buscar tal controle são vários. Segundo o professor Sérgio Amadeu, "no momento em que as operadoras de telefonia começam a perceber que podem transitar em suas redes pacotes de voz sobre ip (VoIP), por exemplo, elas podem querer degradar a velocidade de

Tabela - Tempo de download de acordo com diferentes velocidades de conexão da internet

\begin{tabular}{l|l|l|l|l|l}
\hline DOWNLOAD & $\mathbf{5 6}$ Kbps & $\mathbf{2 5 6}$ Kbps & $\mathbf{2}$ Mbps & 40 Mbps & $\mathbf{1 0 0}$ Mbps \\
\hline Pagina Web (160 KB) & 23 segundos & 5 segundos & 0,64 segundos & 0,03 segundos & 0,01 segundos \\
Home Page (750 KB) & 107 segundos & 23 segundos & 3 segundos & 0,15 segundos & 0.06 segundos \\
Arquivo de música (5 MB) & 12 minutos & 3 minutos & 20 segundos & 1 segundos & 0.4 segundos \\
Vídeo (20 MB) & 48 minutos & 10 minutos & 1 minutos & 4 segundos & 1.6 segundos \\
CD (700 MB) & 28 horas & 6 horas & 47 minutos & 2 minutos & 5 minutos \\
DVD $(4 \mathrm{~GB})$ & 1 semana & 1,5 dia & 4.5 horas & 13 minutos & 5 minutos \\
\hline
\end{tabular}

Fonte: ITU. Tradução: Sérgio Amadeu da Silveira 
